\title{
Correlation, Regression and Path Analyses of Seed Yield Components in Crambe abyssinica, a Promising Industrial Oil Crop
}

\author{
Banglian Huang ${ }^{1}$, Yiming Yang ${ }^{1}$, Tingting $\mathrm{Luo}^{1}$, Shu $\mathrm{Wu}^{1}$, Xuezhu Du${ }^{1}$, Detian Cai ${ }^{1}$, \\ Eibertus N. van $\mathrm{Loo}^{3}$, Bangquan Huang ${ }^{1,2^{*}}$ \\ ${ }^{1}$ College of Life Science, Hubei University, Wuhan, China; ${ }^{2}$ Hubei Industrial Biotechnology Key Lab, Hubei University, Wuhan, \\ China; ${ }^{3}$ Plant Research International, Wageningen, Netherlands. \\ Email: *huangbangquan@163.com
}

Received October $4^{\text {th }}, 2012$; revised November $4^{\text {th }}, 2012$; accepted December $14^{\text {th }}, 2012$

\begin{abstract}
In the present study correlation, regression and path analyses were carried out to decide correlations among the agronomic traits and their contributions to seed yield per plant in Crambe abyssinica. Partial correlation analysis indicated that plant height $\left(\mathrm{X}_{1}\right)$ was significantly correlated with branching height and the number of first branches $(\mathrm{P}<0.01)$; Branching height $\left(\mathrm{X}_{2}\right)$ was significantly correlated with pod number of primary inflorescence $(\mathrm{P}<0.01)$ and number of secondary branches $(\mathrm{P}<0.05)$ and negatively correlated with number of first branches $(\mathrm{P}<0.01)$; Number of first branches $\left(\mathrm{X}_{3}\right)$ was significantly correlated with number of secondary branches $(\mathrm{P}<0.01)$, pod number per plant and 1000 -grain weight $(\mathrm{P}<0.05)$; Number of secondary branches $\left(\mathrm{X}_{4}\right)$ was significantly correlated with seed yield per plant $(\mathrm{P}<0.05)$; Pod number per plant $\left(\mathrm{X}_{7}\right)$ was significantly correlated with seed yield per plant $(\mathrm{P}<0.01)$ and negatively correlated with 1000 -grain weight $(\mathrm{P}<0.01) ; 1000$-grain weight $\left(\mathrm{X}_{8}\right)$ was significantly correlated with seed yield per plant $(\mathrm{P}<0.01)$. Stepwise regression and path analyses indicated that only pod number per plant and 1000 -grain weight contributed significantly to seed yield per plant at $\mathrm{P}<0.01$ and $\mathrm{P}<0.05$, respectively. The regression formula for contributions of pod number per plant $\left(\mathrm{X}_{7}\right)$ and 1000-grain weight $\left(\mathrm{X}_{8}\right)$ to seed yield per plant $(\mathrm{Y})$ is $\mathrm{Y}=0.006 \mathrm{X}_{7}+1.222$ $\mathrm{X}_{8}-7.191$. The path coefficient of pod number per plant to seed yield per plant was 0.967 and that of 1000-grain weight was 0.194 . The determination coefficient of pod number per plant and 1000 -grain weight to seed yield per plant was 0.983 and the determination coefficient of other agronomic traits was 0.130 . Coefficient of variance indicated that the length of primary inflorescence showed the greatest variation, followed by seed yield per plant, pod number per plant, number of secondary branches, branching height, pod number of primary inflorescence, number of first branches, seed yield per plot, 1000-grain weight and plant height. It was suggested that seed yield per plant in Crambe might be improved by increasing the pod number per plant through selection or cultivation, but the negative correlation between pod number per plant and 1000-grain weight also needs to be considered.
\end{abstract}

Keywords: Correlation; Crambe abyssinica; Path Analysis; Regression; Seed Yield Components

\section{Introduction}

Erucic acid is an important fatty acid in the oleochemical industry [1-3]. The current major industrial source of erucic acid is high-erucic acid rapeseed oil [2-4]. In recent years, Crambe abyssinica is becoming more and more interesting as an alternative industrial crop [5-7] since it shows high-erucic acid content $(52 \%-59 \%)$ in its seed oil and also wide climatic and agronomic adaptation and does not cross with the double-low canola. Just recently, the erucic acid content in Crambe seed oil was increased to over 70\% [8]. In addition to oil, Massoura et

${ }^{*}$ Corresponding author. al. [9] reported that other valuable by-products such as protein meal and possibly fiber can be obtained from Crambe. Acceptance of Crambe meal by the feeds Industry is based on its attractive price and satisfactory performance as a feed for ruminant animals [10]. Crambe was also cultivated in China [11]. Since 1970s, traditional breeding by successive selection within C. abyssinica has been carried out in many countries and several cultivars have been released such as "Prophet", "Indy", "Meyer" [12], "BelAnn" and "BelEnzian" [13] by mass selection. Crambe is already commercially cultivated on a small scale, and novel varieties can yield the same amount of oil per hectare as spring rapeseed does [14]. 
Selection, which is mainly based on phenotypic characters, is the major technique used in a breeding program. Response to selection depends on many factors such as the interrelationship of the characters [15]. By knowing if correlation exists between important traits, interpretation on previous results would become easier. Also correlation between important and nonimportant traits provides plant breeding experts with a significant assistance in indirect selection of important traits, through non-important traits which their measurement is easier $[15,16]$. Partial correlation coefficient is a measure of the linear dependence of a pair of random variables from a collection of random variables in the case where the influence of the remaining variables is eliminated. A partial correlation between two variables can differ substantially from their simple correlation [17]. Regression helps to estimate the functional relationship between variables or the relationship between the independent and dependent variables [15]. Path coefficient analysis is a very important statistical tool that can be used to obtain an indication of which variables exert an influence on other variables, while recognizing the multicolinearity $[18,19]$. Path-coefficient analysis has been useful in determining selection criteria in a number of crops, such as crested wheat grass [18], maize [20] and rice [21]. Up to date there is still no report on correlation, regression and path analyses about Crambe seed yield components. Here we report the correlation, regression and path analyses of seed yield components in Crambe to provide some clue to future Crambe breeding and cultivation.

\section{Materials and Methods}

10 Crambe lines from PRI, Wageningen, and 12 lines from Hubei University were sown in Anyue, Sichuan Province in China on October 26, 2011. Anyue is located in Southwest of China and the soil is neutrally purplish. Before sowing the seeds water with farmyard manure was used. For each Crambe line there were three replicates, each replicate $6.6 \mathrm{~m}^{2}$. In each replicate 480 Crambe plants were kept. In December $562.5 \mathrm{~kg}$ urea (about $262 \mathrm{~kg}$ pure N) per hectare was used to promote the growth of Crambe seedlings. The Crambe seeds were harvested On May 1st, 2012 and weighed together with the seed hulls. For each replicate 10 plants were sampled for investigation of the agronomic traits according to the rapeseed standard [22]. Data were analyzed on SPSS 19.0 and Excel.

\section{Results}

\subsection{Seed Yield Performance and Coefficient of Variance for the Agronomic Traits}

Of the 22 Crambe lines tested 19 lines gave seed yield.
Table 1 indicated the average seed yield for each Crambe line and the mean values of the agronomic traits. In general the Crambe seed yields were roughly comparable to that of canola in China. In our experiment the Crambe lines showed great variations with respect to seed yield in each plot as well as to the agronomic traits. The highest seed yield was $2.15 \mathrm{~kg}(3257.58 \mathrm{~kg} / \mathrm{ha})$ for one plot and the lowest was only $0.98 \mathrm{~kg}(1484.85 \mathrm{~kg} / \mathrm{ha})$; The highest seed yield was $53.48 \mathrm{~g}$ for one single plant while the lowest was only $0.96 \mathrm{~g}$; the highest pod number was 8751 for one single plant while the lowest was only 210; the highest 1000 -grain weight was $8.65 \mathrm{~g}$ while the lowest was only $3.4 \mathrm{~g}$.

From Table 2 we see that the length of primary inflorescence $\left(\mathrm{X}_{5}\right)$ showed the greatest variation, followed by seed yield per plant $(\mathrm{Y})$, pod number per plant $\left(\mathrm{X}_{7}\right)$, number of secondary branches $\left(\mathrm{X}_{4}\right)$, branching height $\left(\mathrm{X}_{2}\right)$, pod number of primary inflorescence $\left(\mathrm{X}_{6}\right)$, number of first branches $\left(\mathrm{X}_{3}\right)$, seed yield per plot $(\mathrm{Z}), 1000$-grain weight $\left(\mathrm{X}_{8}\right)$ and plant height $\left(\mathrm{X}_{1}\right)$.

\subsection{Simple and Partial Correlations}

Simple correlation analysis (Table 3 ) indicated that plant height $\left(\mathrm{X}_{1}\right)$ was significantly and positively correlated with branching height, number of first branches, number of secondary branches, pod number of primary inflorescence, pod number per plant, weight per 1000 seeds and seed yield per plant $(\mathrm{Y})(\mathrm{P}<0.01)$ and the length of primary inflorescence $(\mathrm{P}<0.05)$; Branching height $\left(\mathrm{X}_{2}\right)$ was significantly and positively correlated with pod number of primary inflorescence, 1000 -grain weight $(\mathrm{P}<$ 0.01 ), significantly and negatively correlated with the number of first and secondary branches, number of secondary branches, pod number per plant and seed yield per plant $(\mathrm{P}<0.01)$, significantly and positively correlated with the length of primary inflorescence $(\mathrm{P}<0.05)$; the number of first branches $\left(\mathrm{X}_{3}\right)$ was significantly and positively correlated with the number of secondary branches, pod number per plant and seed yield per plant $(\mathrm{P}<$ $0.01)$; the number of secondary branches $\left(\mathrm{X}_{4}\right)$ was significantly and positively correlated with pod number per plant and seed yield per plant $(\mathrm{P}<0.01)$; the length of primary inflorescence $\left(\mathrm{X}_{5}\right)$ was significantly correlated with pod number of primary inflorescence $(\mathrm{P}<0.05)$; pod number of primary inflorescence $\left(\mathrm{X}_{6}\right)$ was significantly correlated with pod number per plant, 1000-grain weight and seed yield per plant $(\mathrm{P}<0.01)$; pod number per plant $\left(\mathrm{X}_{7}\right)$ was significantly correlated with seed yield per plant $(\mathrm{P}<0.01)$; 1000-grain weight $\left(\mathrm{X}_{8}\right)$ was significantly correlated with seed yield per plant $(\mathrm{P}<$ 0.01 ).

Further partial correlation analysis (Table 3) indicated that plant height $\left(\mathrm{X}_{1}\right)$ was significantly correlated with 
Table 1. Average seed yield for each Crambe line and mean values of the agronomic traits.

\begin{tabular}{|c|c|c|c|c|c|c|c|c|c|c|}
\hline Crambe line & $\begin{array}{l}\text { Plant } \\
\text { height } \\
(\mathrm{cm})\end{array}$ & $\begin{array}{l}\text { Branching } \\
\text { height } \\
(\mathrm{cm})\end{array}$ & $\begin{array}{l}\text { No. of first } \\
\text { branches }\end{array}$ & $\begin{array}{c}\text { No. of } \\
\text { secondary } \\
\text { branches }\end{array}$ & $\begin{array}{l}\text { Length of } \\
\text { primary } \\
\text { inflorescence }\end{array}$ & $\begin{array}{l}\text { Pod No. of } \\
\text { primary } \\
\text { inflorescence }\end{array}$ & $\begin{array}{l}\text { Pod No. } \\
\text { per plant }\end{array}$ & $\begin{array}{c}\text { 1000-grain } \\
\text { weight } \\
\text { (g) }\end{array}$ & $\begin{array}{l}\text { Seed yield } \\
\text { per plant } \\
\text { (g) }\end{array}$ & $\begin{array}{l}\text { Average seed } \\
\text { yield per plot } \\
\quad(\mathrm{kg})\end{array}$ \\
\hline HUBU Caby-12 & 94.20 & 7.70 & 20.33 & 77.77 & 13.67 & 19.27 & 1663.8 & 5.09 & 8.61 & $1.67^{\mathrm{a}}$ \\
\hline HUBU Caby-13 & 94.28 & 8.59 & 19.69 & 58.62 & 13.03 & 17.79 & 1577.72 & 5.2 & 8.16 & $1.65^{\mathrm{a}}$ \\
\hline HUBU Caby-07 & 85.00 & 8.2 & 17.5 & 46.8 & 20.7 & 23.7 & 1203.5 & 6.05 & 7.11 & $1.64^{\mathrm{a}}$ \\
\hline HUBU Caby-08 & 93.69 & 9.31 & 18.28 & 59.59 & 13.34 & 15.76 & 1156.79 & 5.24 & 6.03 & $1.59^{\mathrm{a}}$ \\
\hline HUBU Caby-04 & 103.83 & 14.70 & 19.43 & 74.53 & 20.97 & 25.63 & 1754.93 & 6.86 & 11.94 & $1.54^{\mathrm{ab}}$ \\
\hline HUBU Caby-06 & 101.67 & 15.33 & 16.22 & 55.33 & 21.50 & 23.44 & 1025.17 & 5.82 & 6.03 & $1.49^{\mathrm{ab}}$ \\
\hline PRI-Elst 2007-17 & 99.20 & 12.63 & 19.03 & 82.97 & 16.93 & 18.90 & 1255.07 & 5.84 & 7.30 & $1.49^{\mathrm{ab}}$ \\
\hline PRI-Elst 2007-07 & 95.50 & 12.75 & 19.71 & 66.18 & 15.71 & 21.11 & 1234.82 & 5.86 & 7.26 & $1.48^{\mathrm{ab}}$ \\
\hline PRI-Elst 2007-03 & 98.23 & 14.3 & 18.47 & 54.2 & 15.97 & 19.43 & 1054.33 & 5.49 & 5.75 & $1.44^{\mathrm{ab}}$ \\
\hline PRI-Elst 2007-09 & 96.89 & 16.18 & 18.14 & 70.21 & 17.68 & 22.61 & 1203.71 & 5.86 & 6.79 & $1.40^{\mathrm{abc}}$ \\
\hline PRI-Elst 2007-20 & 95.40 & 9.30 & 18.55 & 74.60 & 16.05 & 24.10 & 1352.8 & 6.08 & 8.16 & $1.40^{\mathrm{abc}}$ \\
\hline HUBU Caby-05 & 93.07 & 9.03 & 18.8 & 81.23 & 13.97 & 20.23 & 1840.27 & 5.68 & 10.57 & $1.40^{\mathrm{abc}}$ \\
\hline PRI-Elst 2007-16 & 100.53 & 15.73 & 18.21 & 51.89 & 18.00 & 23.79 & 1272.47 & 5.95 & 7.49 & $1.39^{\mathrm{abc}}$ \\
\hline PRI-Elst 2007-19 & 93.47 & 10.29 & 18.00 & 63.47 & 60.29 & 21.18 & 1003.71 & 4.86 & 4.98 & $1.20^{\mathrm{abc}}$ \\
\hline PRI-Elst 2007-08 & 89.38 & 13.63 & 17.75 & 63.25 & 15.31 & 21.94 & 1080.75 & 5.59 & 6.24 & $1.20^{\mathrm{abc}}$ \\
\hline HUBU Caby-09 & 94.07 & 12.63 & 17.83 & 52.37 & 17.47 & 20.8 & 1036.43 & 6.13 & 6.21 & $1.17^{\mathrm{abc}}$ \\
\hline PRI-Elst 2007-10 & 98.16 & 16.96 & 18.24 & 65.76 & 19.96 & 25.96 & 1343.2 & 6.00 & 7.93 & $1.12^{\mathrm{bc}}$ \\
\hline PRI-Elst 2007-02 & 93.15 & 11.85 & 19.19 & 58.54 & 16.50 & 20.15 & 1110.35 & 5.67 & 6.36 & $1.12^{\mathrm{bc}}$ \\
\hline HUBU-Caby-02 & 103.9 & 8.30 & 23.8 & 127.10 & 14.60 & 18.30 & 2397.8 & 6.02 & 13.91 & $0.99^{\mathrm{c}}$ \\
\hline
\end{tabular}

Note: Average seed yields per plot with different letters were significantly different at $\mathrm{P}<0.05$ level.

Table 2. Coefficient of variance for seed yield per plot and the agronomic traits.

\begin{tabular}{|c|c|c|c|c|c|c|c|c|c|c|}
\hline & Plant height & $\begin{array}{c}\text { Branching } \\
\text { height }\end{array}$ & $\begin{array}{l}\text { No. of first } \\
\text { branches }\end{array}$ & $\begin{array}{l}\text { No. of } \\
\text { secondary } \\
\text { Branches }\end{array}$ & $\begin{array}{c}\text { Length of } \\
\text { primary } \\
\text { inflorescence }\end{array}$ & $\begin{array}{l}\text { Pod No. of } \\
\text { primary } \\
\text { inflorescence }\end{array}$ & $\begin{array}{l}\text { Pod no per } \\
\text { plant }\end{array}$ & $\begin{array}{l}\text { 1000-grain } \\
\text { weight }\end{array}$ & $\begin{array}{l}\text { Seed yield } \\
\text { per plant }\end{array}$ & $\begin{array}{l}\text { Seed yield } \\
\text { per plot }\end{array}$ \\
\hline $\begin{array}{l}\text { Coefficient } \\
\text { of Variance } \\
\text { (cv) }\end{array}$ & 0.1267 & 0.5187 & 0.2293 & 0.5397 & 1.9685 & 0.3320 & 0.7111 & 0.1591 & 0.7432 & 0.2070 \\
\hline
\end{tabular}

branching height and the number of first branches $(\mathrm{P}<$ $0.01)$; Branching height $\left(\mathrm{X}_{2}\right)$ was significantly correlated with pod number of primary inflorescence $(\mathrm{P}<0.01)$ and number of secondary branches $(\mathrm{P}<0.05)$ and negatively correlated with number of first branches $(\mathrm{P}<0.01)$; Number of first branches $\left(\mathrm{X}_{3}\right)$ was significantly correlated with number of secondary branches $(\mathrm{P}<0.01)$, pod number per plant and 1000-grain weight $(\mathrm{P}<0.05)$; Number of secondary branches $\left(\mathrm{X}_{4}\right)$ was significantly correlated with seed yield per plant $(\mathrm{P}<0.05)$; Pod number per plant $\left(\mathrm{X}_{7}\right)$ was significantly correlated with seed yield per plant $(\mathrm{P}<0.01)$ and negatively correlated with 1000-grain weight $(\mathrm{P}<0.01)$; 1000-grain weight $\left(\mathrm{X}_{8}\right)$ was significantly correlated with seed yield per plant $(\mathrm{P}<0.01)$.

\subsection{Regression and Path Analysis}

Stepwise regression and path analyses indicated that the contribution of pod number per plant $\left(\mathrm{X}_{7}\right)$ to seed yield per plant $(\mathrm{Y})$ was highly significant $(\mathrm{P}<0.01)$ and that of 1000 -grain weight $\left(\mathrm{X}_{8}\right)$ was significant $(\mathrm{P}<0.05)$. The 
Table 3. Simple and partial correlations among the Crambe agronomic traits.

\begin{tabular}{|c|c|c|c|c|c|c|c|c|}
\hline & $\begin{array}{l}\text { Branching } \\
\text { height } \\
\left(\mathrm{X}_{2}\right)\end{array}$ & $\begin{array}{l}\text { No. of first } \\
\text { branches } \\
\left(\mathrm{X}_{3}\right)\end{array}$ & $\begin{array}{l}\text { No. of secondary } \\
\text { branches } \\
\left(\mathrm{X}_{4}\right)\end{array}$ & $\begin{array}{l}\text { Length of primary } \\
\text { inflorescence } \\
\left(\mathrm{X}_{5}\right)\end{array}$ & $\begin{array}{l}\text { Pod No. of primary } \\
\text { inflorescence } \\
\left(\mathrm{X}_{6}\right)\end{array}$ & $\begin{array}{l}\text { Pod no per } \\
\text { plant } \\
\left(\mathrm{X}_{7}\right)\end{array}$ & $\begin{array}{l}\text { 1000-grain } \\
\text { weight } \\
\left(\mathrm{X}_{8}\right)\end{array}$ & $\begin{array}{l}\text { Seed yield } \\
\text { per plant } \\
\text { Y }\end{array}$ \\
\hline Plant height & $0.196^{* *}$ & $0.291^{* *}$ & $0.281^{* *}$ & $0.098^{*}$ & $0.223^{* *}$ & $0.417^{* *}$ & $0.136^{* *}$ & $0.434^{* *}$ \\
\hline$\left(\mathrm{X}_{1}\right)$ & $0.380^{* *}$ & $0.185^{* *}$ & 0.017 & 0.083 & 0.062 & 0.070 & 0.050 & -0.005 \\
\hline $\begin{array}{l}\text { Branching height } \\
\qquad\left(\mathrm{X}_{2}\right)\end{array}$ & & $\begin{array}{l}-0.426^{* *} \\
-0.251^{* *}\end{array}$ & $\begin{array}{l}-0.390^{* *} \\
0.104^{*}\end{array}$ & $\begin{array}{l}0.094^{*} \\
0.011\end{array}$ & $\begin{array}{l}0.277^{* *} \\
0.239^{* *}\end{array}$ & $\begin{array}{l}-0.323^{* *} \\
-0.058\end{array}$ & $\begin{array}{c}0.165^{* *} \\
0.051\end{array}$ & $\begin{array}{c}-0.279^{* *} \\
0.015\end{array}$ \\
\hline $\begin{array}{l}\text { No. of first branches } \\
\qquad\left(\mathrm{X}_{3}\right)\end{array}$ & & & $\begin{array}{l}0.692^{* *} \\
0.462^{* *}\end{array}$ & $\begin{array}{l}-0.045 \\
0.007\end{array}$ & $\begin{array}{c}0.056 \\
-0.074\end{array}$ & $\begin{array}{l}0.568^{* *} \\
0.110^{*}\end{array}$ & $\begin{array}{l}0.015 \\
0.104^{*}\end{array}$ & $\begin{array}{l}0.551^{* *} \\
-0.088\end{array}$ \\
\hline $\begin{array}{l}\text { No. of secondary } \\
\text { branches } \\
\left(\mathrm{X}_{4}\right)\end{array}$ & & & & $\begin{array}{l}-0.075 \\
-0.073\end{array}$ & $\begin{array}{l}0.012 \\
0.007\end{array}$ & $\begin{array}{l}0.661^{* *} \\
-0.021\end{array}$ & $\begin{array}{c}0.003 \\
-0.069\end{array}$ & $\begin{array}{l}0.651^{* *} \\
0.101^{*}\end{array}$ \\
\hline $\begin{array}{l}\text { Length of primary } \\
\text { inflorescence } \\
\left(\mathrm{X}_{5}\right)\end{array}$ & & & & & $\begin{array}{l}0.116^{*} \\
0.084\end{array}$ & $\begin{array}{l}-0.009 \\
-0.022\end{array}$ & $\begin{array}{c}0.019 \\
-0.024\end{array}$ & $\begin{array}{l}-0.002 \\
0.023\end{array}$ \\
\hline $\begin{array}{l}\text { Pod No. of primary } \\
\text { inflorescence } \\
\left(\mathrm{X}_{6}\right)\end{array}$ & & & & & & $\begin{array}{c}0.137^{* *} \\
0.000\end{array}$ & $\begin{array}{c}0.130^{* *} \\
0.018\end{array}$ & $\begin{array}{l}0.165^{* *} \\
0.037\end{array}$ \\
\hline $\begin{array}{l}\text { Pod No per plant } \\
\left(\mathrm{X}_{7}\right)\end{array}$ & & & & & & & $\begin{array}{c}-0.020 \\
-0.813 * *\end{array}$ & $\begin{array}{l}0.972^{* *} \\
0.981^{* *}\end{array}$ \\
\hline $\begin{array}{c}1000 \text {-grain weight } \\
\left(\mathrm{X}_{8}\right)\end{array}$ & & & & & & & & $\begin{array}{l}0.174^{* *} \\
0.821^{* *}\end{array}$ \\
\hline
\end{tabular}

Note: Upper, Simple correlation coefficient; Lower, partial correlation coefficient; ${ }^{* *} \mathrm{P}<0.01 ;{ }^{*} \mathrm{P}<0.05$.

contribution of other agronomic traits to seed yield per plant was not significant. The regression formula is $\mathrm{Y}=$ $0.006 \mathrm{X}_{7}+1.222 \mathrm{X}_{8}-7.191$. The path coefficient of pod number per plant to seed yield per plant was 0.967 and that of 1000 -grain weight was 0.194 . The determination coefficient of pod number per plant and 1000-grain weight to seed yield per plant was 0.983 and the determination coefficient of other agronomic traits was 0.130 . The indirect contribution of pod number per plant via 1000 -grain weight and 1000-grain weight via pod number per plant to seed yield per plant were minimal. Figure 1 shows the contributions of pod number per plant and 1000-grain weight and other characters to seed yield per plant.

\section{Discussion}

In the present study simple correlation analysis indicated that seed yield per plant was significantly correlated with plant height, number of first branches, number of seconddary branches, pod number of primary inflorescence, pod number per plant and 1000 -grain weight $(\mathrm{P}<0.01)$ and negatively correlated with branching height $(\mathrm{P}<0.01)$, but partial correlation analysis indicated that seed yield per plant was only significantly correlated with pod number per plant and 1000-grain weight $(\mathrm{P}<0.01)$ and the number of secondary branches $(\mathrm{P}<0.05)$. Simple correlation between pod number per plant and 1000-grain weight was not significant but their partial correlation was negatively significant $(\mathrm{P}<0.01)$.

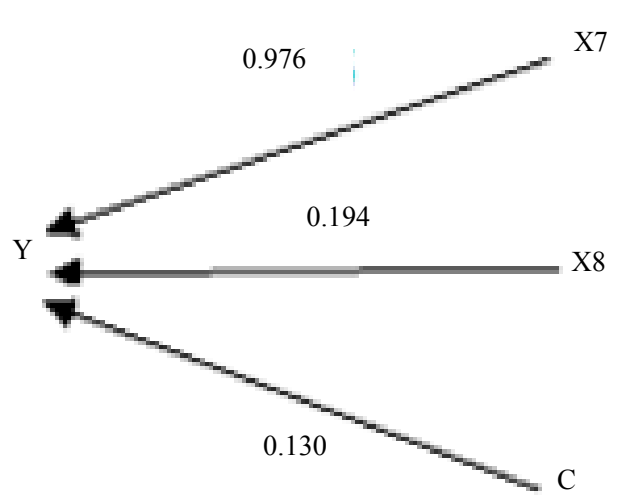

Figure 1. Path model illustrating contributions of pod number per plant $\left(X_{7}\right), 1000$-grain weight $\left(X_{8}\right)$ and other agronomic traits $(C)$ to seed yield per plant $(Y)$.

Previous results about canola indicated that number of pods per plant had the highest direct effect on grain yield in canola. In addition, 1000-grain weight also had a high direct effect on grain yield [23-30]. Tusar-Patra et al. [31] concluded that the strongest effect on seed yield was estimated for number of pods per plant followed by number of seeds per pod and 1000 seed weight. Khan et al. [32] found that number of branches, 1000 -seed weight, and pods per plant affected the seed yield per plant. Marjanović-Jeromela et al. [26] reported that the strongest direct effect on seed yield per plant was estimated for plant height, followed by that of number of pods per plant. Ghodrati et al. [33] found that number of seeds per pod 
was effective on canola seed yield. Results about seed yield components in Orychophragmus violaceus, also a potential crucifer oil crop, indicated that the trait that contributed the most to seed yield per plant was number of pods per plant, followed by number of seeds per pod, 1000-grain weight, and then the number of first branches [34]. In the present study stepwise regression and path analyses indicated that only pod number per plant and 1000 -grain weight contributed significantly to seed yield per plant, while the effects of plant height and branch numbers were not significant. The regression formula for pod number per plant $\left(\mathrm{X}_{7}\right)$ and 1000-grain weight $\left(\mathrm{X}_{8}\right)$ to seed yield per plant is $\mathrm{Y}=0.006 \mathrm{X}_{7}+1.222 \mathrm{X}_{8}-7.191$. The path coefficient of pod number per plant to seed yield per plant was 0.967 and that of 1000-grain weight was 0.194 . The determination coefficient of pod number per plant and 1000-grain weight to seed yield per plant was 0.983 and the left determination coefficient was 0.130 .

In the present study the Crambe seed yields were roughly comparable to that of canola in China and showed great potential to be further increased. In our experiment the Crambe lines showed great variations with respect to seed yield in each plot as well as to the agronomic traits. The highest seed yield was $2.15 \mathrm{~kg}$ $(3257.58 \mathrm{~kg} / \mathrm{ha})$ for one plot and the highest seed yield was $53.48 \mathrm{~g}$ for one single plant; the highest pod number was 8751 for one single plant and the highest 1000 -grain weight was $8.65 \mathrm{~g}$. Coefficient of variance indicated that seed yield per plant and pod number per plant showed great variations. Combined with the results from regression and path analyses, it was suggested that seed yield per plant in Crambe might be improved by increasing the pod number per plant through selection or cultivation, still the negative correlation between pod number per plant and 1000-grain weight also needs to be considered.

\section{Acknowledgements}

This work was supported by an EC FP7 project ICON (211400), Swedish Research Links project, funds from NSFC (30771382, 30671334, 30971807, 31201238), Wuhan Science and Technology Bureau and MOST, China.

\section{REFERENCES}

[1] N. O. V. Sonntag, "Erucic, Behenic: Feedstocks of the 21st Century," Informatics, Vol. 2, No. 5, 1991, pp. 449463.

[2] C. Leonard, "Sources and Commercial Applications of High Erucic Vegetable Oils," Lipid Technology, Vol. 6, No. 4, 1994, pp. 79-83.

[3] G. J. Piazza and T. A. Foglia, "Rapeseed Oil for Oleochemical Uses," European Journal of Lipid Science and
Technology, Vol. 103, No. 7, 2001, pp. 405-454. doi:10.1002/1438-9312(200107)103:7<450::AID-EJLT45 0>3.0.CO;2-D

[4] N. O. V Sonntag, "Industrial Utilization of Long-Chain Fatty Acids and Their Derivatives," In: D. S. Kimber and D. I. McGregor, Eds., Brassica Oilseeds, CAB International, Oxon, 1995, pp. 339-352.

[5] K. L. Mikolajczak, T. K. Miwa, F. R. Earle and I. A. Wolff, "Search for New Industrial Oils. V. Oils of Cruciferae," Journal of the American Oil Chemists' Society, Vol. 38, No. 12, 1961, pp. 678-681. doi:10.1007/BF02633053

[6] L. Lazzeri, O. Leoni, L. S. Conte and S. Palmieri, "Some Technological Characteristics and Potential Uses of Crambe abyssinica," Industrial Crops and Products, Vol. 3, No. 1-2, 1994, pp. 103-112. doi:10.1016/0926-6690(94)90083-3

[7] J. C. Gardner, "Crambe: New Routes from Farm to Market,” Informatics, Vol. 7, No. 9, 1996, pp. 986-989.

[8] X. Li, E. N. van Loo, J. Gruber, J. Fan, R. Guan, M. Frentzen, S. Stymne and L.-H. Zhu, "Development of Ultra-High Erucic Acid Oil in the Industrial Oil Crop Crambe abyssinica," Plant Biotechnology Journal, Vol. 10, No. 7, 2012, pp. 862-870. doi:10.1111/j.1467-7652.2012.00709.x

[9] E. Massoura, J. M. Vereijken, P. Kolster and J. T. P. Derksen, "Isolation and Functional Properties of Proteins from Crambe abyssinica Oil Seeds," In: J. Janick, Ed., Progress in New Crops, ASHS Press, Alexandria, 1996, pp. 322-327.

[10] K. D. Carlson, J. C. Gardner, V. L. Anderson and J. J. Hanzel, "Crambe: New Crop Success," In: J. Janick, Ed., Progress in New Crops, ASHS Press, Alexandria, 1996, pp. 306-322.

[11] Y. P. Wang, J. S. Tang, C. Q. Chu and J. Tian, "A Preliminary Study on the Introduction and Cultivation of Crambe abyssinica in China, an Oil Plant for Industrial Uses," Industrial Crops and Products, Vol. 12, No. 1, 2000, pp. 47-52.

[12] K. J. Lessman, "Variation in Crambe, Crambe abyssinica Hochst," Journal of the American Oil Chemists' Society, Vol. 52, No. 9, 1975, pp. 386-389. doi:10.1007/BF02639202

[13] T. A. Campbell, J. Crock, J. H. Williams, A. N. Hang, R. E. Sigafus, A. A. Schneiter, C. R. McClain, C. R. Graves, D. G. Wooley, R. Kleiman and W. C. Adamson, "Registration of 'Belann' and 'Belenzian' Crambe," Crop Science, Vol. 26, No. 5, 1986, pp. 1082-1083. doi:10.2135/cropsci1986.0011183X002600050056x

[14] C. Temple-Heald, "High Erucic Oil: Its Production and Uses,” In: F. D. Gunstone, Ed., Rapeseed and Canola Oil: Productions, Properties and Uses, Blackwell Publishing, CRC Press, Oxford, 2004, pp. 111-129.

[15] B. K. Joshi, "Correlation, Regression and Path Coefficient Analyses for Some Yield Components in Common and Tartary Buckwheat in Nepal," Fagopyrum, Vol. 22, 2005, pp. 77-82. 
[16] A. Qulipor, N. Latifi, K. Qasemi and M. Moqadam, "Comparative Growth and Grain Yield of Canola under Dry Land Conditions in Gorgan," Journal of Agriculture Science and Natural Resource, Vol. 11, No. 1, 2004, pp. $5-14$.

[17] G. E. Dallal, "Partial Correlation Coefficients," 2001. http://www.jerrydallal.com/LHSP/partial.htm

[18] D. R. Dewey and K. H Lu, "A Correlation and Path-Coefficient Analysis of Components of Crested Wheatgrass Seed Production," Agronomy Journal, Vol. 51, No. 9, 1959, pp. 515-518. doi:10.2134/agronj1959.00021962005100090002x

[19] S. I. Akanda and C. C. Mundit, "Path Coefficient Analysis of the Effects of Stripe Rust and Cultivar Mixtures on Yield and Yield Components of Winter Wheat," Theoretical and Applied Genetics, Vol. 92, No. 6, 1996, pp. 666-672. doi:10.1007/BF00226087

[20] M. Ivanovic and K. Rosie, "Path Coefficient Analysis for Three Stalk Traits and Grain Yield in Maize (Zea mays L.)," Maydica, Vol. 30, No. 3, 1985, pp. 233-239.

[21] S. O. PB. Samonte, L.T. Wilson and A. M. McClung, "Path Analyses of Yield and Yield-Related Traits of Fifteen Diverse Rice Genotypes," Crop Science, Vol. 38, No. 5, 1998, pp. 1130-1136. doi:10.2135/cropsci1998.0011183X003800050004x

[22] H. L. Liu, "Genetics and Breeding of Rapeseed," Shanghai Scientific and Technical Publishers, Shanghai, 1985.

[23] F. A. Khan, S. Ali, A. Shakeel, A. Saeed and G. Abbas, "Correlation Analysis of Some Quantitative Characters in Brassica napus L.," Journal of Agricultural Research, Vol. 44, No. 1, 2006, pp. 7-14.

[24] R. Baradaran, A. Majidiharvan, F. Darvish and M. Azizi, "Relationship between Correlation and Path Coefficient Analysis of Yield in Canola," Journal of Agricultural Sciences, Vol. 12, No. 4, 2006, pp. 127-139.

[25] M. Akbar, U. T. Saleem, M. Yaqub and N. Iqbal, "Utilization of Genetic Variability, Correlation and Path Analysis for Seed Yield Improvement in Mustard, Brassica juncea L.," Journal of Agricultural Research, Vol. 45, No.1, 2007, pp. 25-31.

[26] A. Marjannović-Jeromela, R. Marinković, A. Mijić, Z.
Zdunić, S. Ivanovska and M. Jankulovska, "Correlation and Path Analysis of Quantitative Traits in Winter Rapeseed (Brassica napus L.)," Agriculturae Conspectus Scientificus, Vol. 73, No. 1, 2008, pp. 13-18.

[27] M. Khayat, Sh. Lack and H. Karami, "Correlation and Path Analysis of Traits Affecting Grain Yield of Canola (Brassica napus L.) Varieties," Journal of Basic and Applied Scientific Research, Vol. 2, No. 6, 2012, pp. 55555562.

[28] N. Thurling, and L. D. V. Das, "The Relationship between Pre-Anthesis Development and Seed Yield of Spring Rape (Brassica napus L.)," Australian Journal of Agricultural Research, Vol. 31, No. 1, 1979, pp. 25-36. doi:10.1071/AR9800025

[29] H. Ozer, E. Oral and U. Dogru, "Relationship between Yield and Yield Components on Currently Improved Spring Rapeseed Cultivars," Turkish Journal of Agriculture and Forestry, Vol. 23, 1999, pp. 603-607.

[30] N. Ali, F. Javidfar, J. Y. Elmira and M. Y. Mirza, "Relationship among Yield Components and Selection Criteria for Yield Improvement in Winter Rapeseed (Brassica napus L.)," Pakistan Journal of Botany, Vol. 35, No. 2, 2003, pp. 167-174.

[31] P. Tusar, S. Maiti and B. Mitra, "Variability Correlation and Path Analysis of the Yield Attributing Characters of Mustard (Brassica spp.)," Research on Crops, Vol. 7, No. 1, 2006, pp. 191-193.

[32] A. Khan, M. Rahim, A. Khan, M. I. Khan and S. Riaz, "Correlation and Path Coefficient Analysis for Yield Contributing Traits in Brassica napus," Pakistan Journal of Agricultural Research, Vol. 16, No. 2, 2000, pp. 127130.

[33] G. R. Ghodrati, S. H. Mahmoodinejadedezfuly and A. Gholami, "Correlation and Path Coefficient Analysis of Seed Yield Components in Spring Canola (Brassica napus L.)," Journal of Basic and Applied Scientific Research, Vol. 1, No. 11, 2011, pp. 2009-2013.

[34] B. Huang, P. Luo, Y. Chen and S. Zhou, "Correlations, Regression and Path Analyses of the Components of the Seed Yield per Se in Orychophragmus violaceus under Cultivation," Oil Crops in China, Vol. 19, No. 4, 1997, pp. 19-21. 